\title{
Erratum to: Methodology to Identify Poly-ADP-Ribose Polymerase 1 (PARP1)-mRNA Targets by PAR-CLiP
}

\section{Manana Melikishvili, Elena Matveeva, and Yvonne Fondufe-Mittendorf}

\section{Erratum to:}

Chapter 15 in: Alexei V. Tulin (ed.), Poly(ADP-Ribose) Polymerase:

Methods and Protocols, Methods in Molecular Biology, vol. 1608, DOI 10.1007/978-1-4939-6993-7_15

In Chapter 15, titled "Methodology to Identify Poly-ADP-Ribose Polymerase 1 (PARP1)mRNA Targets by PAR-CLiP", an author's name was corrected to read as follows:

Manana Melikishvili 